Gedas Baranauskas,

Mykolas Romeris University, Lithuania

iD ORCID ID, 0000-0002-8980-8203

Correspondence author: gedas.baranauskas@yahoo.com

\title{
DIGITALIZATION IMPACT ON TRANSFORMATIONS OF MASS CUSTOMIZATION CONCEPT: CONCEPTUAL MODELLING OF ONLINE CUSTOMIZATION FRAMEWORKS
}

Abstract. This paper summarizes the main theoretical points within the scientific discussion on the issue of digitalization in Mass Customization concept and online Mass Customization frameworks. Origins of a stand-alone Mass Customization concept drawback to the second half of the 1990s, but major theoretical content changes and development have been identified in the last 2 decades. An intensive application of combined technology and management solutions, digital society and business transformations in the past decade has shifted the orientation of the concept to intangible products management, customer involvement and mutual value creation via frameworks in the online environment. The main purpose of the research is to reveal and present the role and impact of the digitalization sub-domain to the Mass Customization concept, its transition to the e-concept version and modelling of new combined online customization frameworks. The decision relevance of this scientific problem is multiple issues in transitions of practical organizations to the modern and mixed technological-management approach-based Mass Customization version as well as application limitations of existing online customization frameworks. The analysis of the research topic is carried out in the logical sequence. Firstly, the author presented the influence of the digitalization sub-domain to theoretical transformations of traditional Mass Customization concept. Then, a case study of the organizational transition to electronic Mass Customization and Personalization and online customization frameworks was conducted. Methodological tools and research methods used in the paper have been integrative literature review and narrative synthesis of qualitative findings of 53 articles, and a simplified Robinson conceptual modelling framework together with a c-tuple method for the simulation of new combined online customization frameworks. The research empirically confirms and theoretically proves that within last decade both practical and academic attention to sustainable and agile development of new, fully digital customized products and personalized services as well as flexible online customization frameworks and solutions significantly have increased. Furthermore, here the extent by 6 new online customization frameworks is offered next to 3 standard theoretical online customization frameworks, which became difficult to apply in the environment and preferences of modern e-business organizations and digital end-users. The results of the research can be useful for continuous scientific researches to test and validate 6 new online customization frameworks in a feedback loop part and evaluate the influence of these frameworks to a digital end-user behaviour, their role in frameworks and attitude aspects.

Keywords: customization, digital, online frameworks, personalization, standardization.

Introduction. Over three decades of efficient adaptation, the Mass Customization concept has resulted in numerous practical transitions and transformations as well as gained a label of a suitable strategy and business model to apply in the constantly changing context of digitalization and sustainability trends. Moreover, it leads to an open consideration as being one of leading concepts in reducing the gap and satisfying design and participation needs of online customers, supporting modelling their behaviour as well as encouraging business improvements and competitive advantage through combined management and technology innovations (Risdiyono and Komsap, 2013; Xu et al., 2016; Xu et al., 2017). Moreover, it is noticed that this digital transformation progresses more slowly in traditional manufacturing organizations and in markets with low-tech specifics as well as a low adoption rate of Mass Customization overall due to homogeneous needs of end-users and Mass Production effectiveness (Broekhuizen and Alsem 2002; Kanama, 2018). Furthermore, this practical transitions and application issues undoubtedly

Cite as: Baranauskas, G. (2020). Digitalization Impact on Transformations of Mass Customization Concept: Conceptual Modelling of Online Customization Frameworks. Marketing and Management of Innovations, 3, 120-132. http://doi.org/10.21272/mmi.2020.3-09 

Online Customization Frameworks.

appear as the root cause of new diffusions and combinations of this research domain in online and digitalization related outcomes in the past decade and stimulus on continuous analyses at theoretical case levels. Therefore, this research paper aims to summarize main theoretical points within the scientific discussion on the Digitalization impact on the Mass Customization concept, its transition to the e-concept version and modelling of new combined online mass customization frameworks.

Literature Review. During the three decades of researches, the Mass Customization concept has experienced a few transformations in the theoretical framework as well as in the practical application background. It has been mostly related to a widespread semantical meaning and a changed role of core Personalization and Digitalization subdomains. Herewith, a tremendous impact on the concept content should be noted by disclosing an influence of the Digitalization phenomenon and combined factors of the complex organizational environment and hybrid management methods like Lean and Agile (Abdallah and Matsui, 2009; Vekic et al., 2018). As per below, Figure 1 illustrates a simplified transformation direction of the Mass Customization concept framework retrospectively for the last 3 decades (Figure 1).

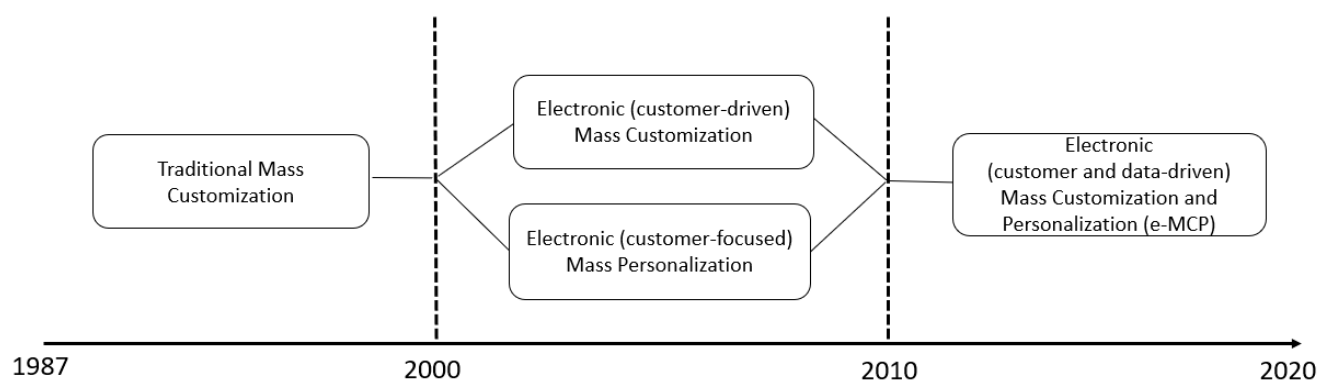

Figure 1. Main directions of transformation in Mass Customization concept within 1987-2020

Source: developed by the author based on Kaplan and Haenlein, 2006; Anisic et al., 2013, Kanama, 2018; Zhang et al., 2019; Wang et al., 2020.

In the first decade of Mass Customization research (1987-2000) a predominant approach was built on assumptions that a clear degree of a product variety, its modularity features or a specific stage and amount of customer involvement time defined critical success factors and features of efficient customization. However, technological advancements and digitalization here were understood only as complementary, assisting parts in a linear and sequential Customization process (Gilmore and Pine, 1997; Reichwald et al., 2000; Sophie-Lee et al., 2000). Following Figure 1, it can be stated that starting from the 2000 s, the traditional version of the Mass Customization concept has shifted theoretical boundaries and main orientation to electronic (e-Mass Customization and Personalization) versions and increased attention to the usability of its online frameworks (McCarthy, 2004; Kamis et al., 2004, 2008; Schubert, 2006; Daaboul et al., 2009; Morelli and Nielsen, 2009). Furthermore, combined topics of Digitalization and Personalization are recognized as one of the key research sub-domains in the Mass Customization research in the past decade (Anisic et al., 2013; Joergensen et al., 2014; Brandao et al., 2016; Xu et al., 2016; Wang et al., 2017; Kanama, 2018). It is important to mention that these sub-domains also played a role in an earlier period of Mass Customization research, where Personalization sub-domain constantly overlaps with the Digitalization sub-domain in different contexts. However, both sub-domains were more recognized as a solution for traditional customization obstacles or at least a way to minimize its negative influence for an end-user and organizations. On the other hand, Digitalization impact during time developed and became a stand-alone factor and a separate research sub-domain. It has had a significant role in the Mass 
G., Baranauskas. Digitalization Impact on Transformations of Mass Customization Concept: Conceptual Modelling of Online Customization Frameworks.

Customization concept background and development as well as has outcome in various theoretical and practical reflections forms:

- In digital customer experience and journey management.

- In digital touchpoints set up.

- In digitalize of customization processe.

- In the creation and usage of online customization frameworks (Risdiyono et al., 2016; Zhang et al., 2019; Weber and Chatzopoulos, 2019).

To be more specific, the key role and impact of digitalization have featured in presenting the possible options of online customization frameworks to an end-user, which at the theoretical level were firstly introduced by Kamis, Koufaris and Stern (Kamis et al., 2004,2008). Moreover, 3 hypothetical online customization frameworks refined and extended standard task-technology acceptance models and rational behaviour theories. These frameworks combine not only different levels of application of Personalization, Customization and Standardization concepts but also illustrate how focus to digital consumers experience management, appropriate personalized communication and information management solutions and knowledge and gamification based interface can be successfully applied in online customization practice (Kamis et al., 2008; Karwatzki et al., 2017; Lai, 2017; Weber and Chatzopoulos, 2019). Secondly, it is argued that, in the practice of connection modalities which consist of online sales configurators, recommenders and social web technologies, these frameworks together with overall technological progress, consumer behaviour trends of socializing and globalizing decisions have had a revolutionary impact across e-retailers organizations. The influence includes increasing total sales numbers, achieving a manageable cost structure and cost level, maximizing online shoppers experience and affecting their cognitive, affective, and behavioural attitudes (Küster, 2016; Vekic et al., 2018; Grosso and Forza, 2019). Furthermore, internet and high-tech organizations seem to be one of the major factors to have influenced the growth and popularity of the e-concept versions and frameworks (Brandao et al., 2016). Additionally, it should be noted that in the new frameworks of this concept, also recognized as a Smart or Agile Customization, data and data-driven digital processes are primary organizational capabilities and final Customization qualifications applied in modern organizations (Zhang et al., 2019; Wang et al., 2020). On the other hand, it should be mentioned that researches of Mass Customization domain claim that typically organizations struggle to underline all potential benefit of customization as organizations tend to adopt and implement this mixed technological-management approach by inertia or only partly. These are well recognized practical obstacles in customer interaction systems, experience management or web-based product co-creation configurations. They are missing a set up of complementary processes for a smooth transition to customization focused business operations model, for example, employee pieces of training, rebranding and communication campaigns, quality management and their coordination (Piller et al., 2014; Wang et al., 2015; Hora et al., 2016). Thus, implementation of customization ideas and frameworks requires not only having a strong technological foundation but also going through a wide scope and multidimensional transformation including significant organizational structure changes, applying a different approach to value creation systems and processes, new methods and tools for knowledge, supply chain and interaction management with end-users, corporate social responsibility and environmental sustainability (Piller et al., 2014; Hora et al., 2016; Zhang et al., 2019). This practical situation also illustrates key research gaps and interest fields of modern Mass Customization research. In summary, it should be noticed that Personalization or Digitalization sub-domains have significantly changed their role and directly influenced transformations of the Mass Customization framework and practical application. In the first decade of researches (1987-2000) sub-domains of Personalization and Digitalization did not receive enough interest from scientific studies as they were perceived taking a role of a consequence or a circumstance in regards of customization. However, the last two decades have brought them as individual subjects, and, accordingly, they have been taken into 
G., Baranauskas. Digitalization Impact on Transformations of Mass Customization Concept: Conceptual Modelling of Online Customization Frameworks.

consideration as both stand-alone and combined research objects. Furthermore, the knowledge of Mass Customization and Mass Personalization concepts and good practices in the past decade widespread to both traditional manufacturing-based sectors and service-orientated organizations. On the other hand, the approach to the application should be marked as an existing sectoral distingue, which is confirmed on the popularity of Mass Personalization in the public service domain. At the same time, Mass Customization possesses a strong vitality and position in the private service and tangible products domain. Following the literature review, this research paper consists of a theoretical discussion within the following aims and hypotheses.

1. To reveal the role and influence of the Digitalization domain to the Mass Customization concept development and its 3 capabilities.

2. To present the main possibilities and challenges of an organizational transition to the eCustomization concept version and application of online customization frameworks. Here the author generates a first research hypothesis $(\mathrm{H} 1)$ : Digitalization domain has influenced the transformation of the Mass Customization domain in the last 2 decades.

3. To conduct conceptual modelling of new combined online customization frameworks. Here the author generates a second research hypothesis $(\mathrm{H} 2)$ : new combined online customization frameworks can be modelled next to 3 standard Kamis et al. online customization frameworks.

Methodology and research methods. The present paper follows a mixed methodology of qualitative and quantitative research with analytical methods and the nature of the study. Moreover, the research design of 2-stage convergent parallel exploratory has been selected and applied by using a combined qualitative and quantitative data collection and analysis methods:

- The simplified Retrospective Process Chart for holistic analysis and presentation of main historical points and context of the modern Mass Customization research area.

- An integrative literature review and synthesis of qualitative findings from 58 scientific papers graphical visualization of main results.

- A simplified Robinson (2008a, 2008b, 2015) conceptual modelling framework and a simplified logic of Cartesian product creation by using the c-tuple method. The modification of the traditional Robinson (2008a, 2008b, 2015) conceptual modelling framework used by the author is provided in Figure 2 while the formula of the c-tuple method used in simulation process is provided:

$$
\begin{aligned}
& \mathrm{F}(\mathrm{x})=\$ \mathrm{~F} \$ 1+\$ \mathrm{Fn}=\{\$ \mathrm{C} \$ 1, \$ \mathrm{P} \$ 1, \$ \mathrm{~S} \$ 1\}+\{\$ \mathrm{Cn}, \$ \mathrm{Pn}, \$ \mathrm{Sn}\} \\
& \mathrm{F}(\mathrm{x})=\$ \mathrm{~F} \$ 2+\$ \mathrm{Fn}=\{\$ \mathrm{C} \$ 2, \$ \mathrm{P} \$ 2, \$ \mathrm{~S} \$ 2\}+\{\$ \mathrm{Cn}, \$ \mathrm{Pn}, \$ \mathrm{Sn}\} \\
& \mathrm{F}(\mathrm{x})=\$ \mathrm{~F} \$ 3+\$ \mathrm{Fn}=\{\$ \mathrm{C} \$ 3, \$ \mathrm{P} \$ 3, \$ \mathrm{~S} \$ 3\}+\{\$ \mathrm{Cn}, \$ \mathrm{Pn}, \$ \mathrm{Sn}\}
\end{aligned}
$$

where Fx - new online customization framework; F1 - Alternative based online customization framework; F2 Attribute-based online customization framework; F3 - Question based online customization framework; Fn - one of Alternative based, Attribute-based or Question-based online customization framework; C1 - the level of customization in Alternative based online customization framework; C2 - the level of customization in Attribute-based online customization framework; C3 - the level of customization in Question-based online customization framework; $\mathrm{Cn}$ the level of customization one of Alternative based, Attribute-based or Question-based online customization framework; P1 - the level of personalization in Alternative based online customization framework; P2 - the level of personalization in Attribute-based online customization framework; P3 - the level of personalization in Question-based online customization framework; $\mathrm{Pn}$ - the level of personalization one of Alternative based, Attribute-based or Question-based online customization framework; S1 - the level of standardization in Alternative-based online customization framework; S2 - the level of standardization in Attribute-based online customization framework; S3 the level of standardization in Question-based online customization framework; $\mathrm{Sn}$ - the level of standardization one of Alternative based, Attribute-based or Question-based online customization framework.

Source: developed by the author based on Haag, 2017; Haag and Haag, 2019. 
G., Baranauskas. Digitalization Impact on Transformations of Mass Customization Concept: Conceptual Modelling of Online Customization Frameworks.

Application of combined methods allows disclosing the state-of-the-art and identifying relevant research trends and patterns in the Mass Customization topic. On the other hand, the author agrees with main limitations of the literature review research method, which has influenced this paper and should be considered in the further topic investigation: fragmentation in analysis period and scope; lack of interdisciplinary approach; risk of flawed assumptions and conclusions as well as not truly integrative results (Burke and Hutchins, 2007; Snyder, 2019). Notably, performing a systematic review and synthesizing qualitative and quantitative evidence is challenging because of multiple synthesis options, therefore, in future researches a systematic mixed studies review (SMSR)) should be performed (Hong et al., 2017). Moreover, results of this paper should be verified by applying a more comprehensive systematic or semi-systematic review and bibliometric analysis, including Web of Science (Clarivate Analytics) (WoS) database and graphical visualization with VOSviewer (www.vosviewer.com) software. For fulfilling both aims and the rest of the research, a relevant integrative review has been performed while, for simulation of new combined online customization frameworks, a simplified Robinson (2008a, 2008b, 2015) conceptual modelling framework and a c-tuple method have been selected.

Results. Key theoretical points for successful online customization frameworks application. Modern versions of Mass Customization concept and practical online customization frameworks bring a new level and speed to customer service, supply chain, configurators and/or recommenders' systems. Moreover, they also stand for a variety of new challenges in organizations. It is because of the need of not only changing a strategy and operational model but also transforming IT infrastructure, ensuring a smooth employee re-training process, high cybersecurity and overall data protection standards at the same time. Retrospectively, this type of a user-driven product or service self-Customization and its digitalization have also been strongly affected by recent trends and risks of automation, data management and the fourth Data (industrial) Revolution. The period 2000-2010 marks the concept transition from traditional, organization-driven Mass Customization to a customer-driven e-Customization and e-Personalization. It covers an increased focus to customer involvement and Big Data and application of its analytics results to customization processes and systems (Forbes and Schaefer, 2017; Rodseth et al., 2017; Wang et al., 2017; Zhang et al., 2019). Now it is agreed that value proposition parts related to the customer in customization are mostly produced on the informational level, and only a data-based product on an electronic platform can be fully tailored to the needs of a specific customer (Reichwald et al., 2000; Schubert, 2006; Wang et al., 2017; Zhang et al., 2019). Coming back to online customization frameworks as being innovative, practical outcomes of e-MCP concept, modern organizations here still face a list of internal and external challenges. These challenges are specified in Table 1.

Table 1. Main internal and external challenges for online customization frameworks application

\begin{tabular}{|l|l|}
\hline \multicolumn{1}{|c|}{ Internal challenges } & \multicolumn{1}{|c|}{ External challenges } \\
\hline $\begin{array}{l}\text { Selection of right trade-off between standardization, } \\
\text { customization and personalization }\end{array}$ & Higher end-user awareness and knowledge level \\
\hline $\begin{array}{l}\text { Full modularization of product/service, company's people, } \\
\text { processes/systems }\end{array}$ & The circular and sharing economy \\
\hline $\begin{array}{l}\text { Limited organizational capabilities for the transition to the } \\
\text { new version of the customization }\end{array}$ & $\begin{array}{l}\text { Corporate social responsibility and environmental } \\
\text { sustainability }\end{array}$ \\
\hline $\begin{array}{l}\text { Full transition to a business model with the dominance of } \\
\text { value proposition elements }\end{array}$ & $\begin{array}{l}\text { The shift of dominant demographic cohorts to } \\
\text { Generation Y, Generation Z and Generation Alpha }\end{array}$ \\
\hline
\end{tabular}

Source: developed by the author based on Salvador et al., 2009; Piller et al., 2014; Pourabdollahian, 2014a, 2014b; Risdiyono et al., 2016; Francis and Hoefel, 2018; Vekic et al., 2018; Zhang et al., 2019.

As per Table 1, in the past decade, rapid development of Information and Communication Technology (ICT) as well as internet and e-commerce industry not only have influenced the emergence of combined 
G., Baranauskas. Digitalization Impact on Transformations of Mass Customization Concept: Conceptual Modelling of Online Customization Frameworks.

online customization frameworks and their modes. It also revealed several opportunities and challenges. Both representatives of pure e-retailers and traditional $\mathrm{B} 2 \mathrm{C}$ organizations, which are in transition to online customization and omnichannel approach, understood that competitive advantage was gained not only by a low price strategy and strong branding. It also was achieved by more efficient utilization of resources, offer of different customized service modes and improved value proposition to end-user by solving their specific problems (Verhoefa et al., 2015; Yao, 2017, Vekic et al., 2018; Zhao et al., 2018; Lee et al., 2019). Furthermore, for achieving the goal, both type of organizations should overcome such internal obstacles as a selection of right trade-off between standardization, customization and personalization at strategy and operational levels. It should ensure a full scope of modularization not only of product or service but also of the company's people and processes. Standard B2C organizations at this point have additional challenges of dealing with limited organizational, mostly technical, capabilities, which is necessary for a transition to data-based digital processes and qualifications of e-MCP. To be more specific, the transition to Mass Customization service business model in practice is defined under the model called Customer to Business to Manufactory based on Mass Customization (C2B2M-MC) and 5 specific operations models (Zhang et al., 2019). Next to the above listed internal challenges, the Mass Customization concept also request to align with higher end-user awareness and knowledge level, which is an integral feature of generation $Y$, generation $Z$ and will be standard in generation Alpha. Beforehand mentioned demographic cohorts of generation $Y$ and generation $Z$ are becoming dominant in the society not only from a statisticalproportional point of view but by their digital natives, personalized communication, economic scalability, uniqueness requirements. Even though generation Alpha is currently at a pre-stage, they have a strong influence for millennials by creating an intense and borderline relationship model and changing their spending behaviour and stimulating a need for customized service and/or product in online (Carter, 2016; Francis and Hoefel, 2018). Moreover, some general trends affect the popularity of e-Customization and widespread of combined online customization frameworks. A circular and sharing type economy have increased demand for more active corporate social responsibility and sustainability activities and better digitally customized products with an environmentally friendly label and full process automation (Rungtusanatham and Salvador, 2008; Gandhi et al., 2013; Hu, 2013; Hankammer and Steiner, 2015; Medini et al., 2015; Tiihonen and Felfernig, 2017).

Therefore, the modern Mass Customization concept requests a set of new key activities, management of above-listed challenges and application of combined online customization frameworks to be competitive in the mass market and efficiently provide customized and innovative products to an end-user.

Theoretical modelling of new online customization frameworks. A selection and combination of the online customization framework depend on multiple reasons, including internal and external organizational challenges defined in Table 1 as well as evaluating numerous micro features and the context of the application. It could be a product or service complexity, pricing model, legal base; access and management of user information; customer relationship or marketing strategy; the role of end-user and actions limits (Kamis et al., 2004; Park and Yoo, 2018; Wang, 2019, Baranauskas, 2020). Three standard online customization frameworks are defined in Table 2.

Table 2 allowed stating that, there are a wider scope and variety of solutions and combinations in online customization frameworks in the organizational practice. There is a need for several distinct factors, which influenced the development of these frameworks and overall e-MCP concept:

a) organizational efforts to maximize the return of investment (ROI) and other quantitative operational indicators in online business model by aligning and combining features of Mass Production, Mass Customization and Digitalization domain. Personalization at this point has a twofold meaning and serves as both an intermediary stage in the transition process and a key supplementary feature of modern Mass Customization version; 
G., Baranauskas. Digitalization Impact on Transformations of Mass Customization Concept: Conceptual Modelling of Online Customization Frameworks.

b) rapid and natural change of end-user behaviour, knowledge level and attitude to customized products or service providers, which can be moderated by an organization only by setting up limits for actions in the customization process.

Table 2. Three main online customization frameworks

\begin{tabular}{|c|c|c|c|}
\hline \multirow{2}{*}{ Type } & \multicolumn{3}{|c|}{ Features } \\
\hline & Customization & Personalization & Standardization \\
\hline $\begin{array}{l}\text { Alternative-based (AL-B): } \\
\text { 1. Applicable for product/service with } \\
\text { limited and low customization and/or } \\
\text { personalization possibilities. } \\
\text { 2. The final design of product/service } \\
\text { is delivered. } \\
\text { 3. Role of end-user is passive and } \\
\text { limited by the only selection of } \\
\text { customized product/service. }\end{array}$ & Low & Low & High \\
\hline $\begin{array}{l}\text { Attribute-based (AT-B): } \\
\text { 1. Applicable for product/service with } \\
\text { high customization possibilities. } \\
\text { 2. Personalization features are used } \\
\text { to assist end-user in product/service } \\
\text { customization process, mostly in the } \\
\text { design stage. } \\
\text { 3. Role of end-user is more active } \\
\text { and engage in co-design activities. } \\
\end{array}$ & High & Middle & Middle \\
\hline $\begin{array}{l}\text { Question-based }(Q-B) \text { : } \\
\text { 1. Applicable for the bespoke type of } \\
\text { product/service where build from } \\
\text { scratch is available. } \\
\text { 2. Role of end-user is non-limited and } \\
\text { active participation in all stages of the } \\
\text { customization process. }\end{array}$ & High & High & Low \\
\hline
\end{tabular}

Source: developed by the author based on Kamis et al., 2004.

Therefore, next to Kamis et al. (2004), 3 main theoretical frameworks of online customization can be formed 6 combined frameworks, which incorporate 3 level values of customization, personalization and standardization application. Theoretical frameworks were created by using a modified conceptual modelling framework of Robinson (2008a, 2008b, 2015) and following a simplified logic of creating a Cartesian type of product with the c-tuple method in the backend. The conceptual modelling framework in this research stands for a high-level abstraction process of a simulation model from the part of the real system. It has a meaning that Kamis et al. (2004) suggested as 3 online customization frameworks. The main objective is to simulate and provide new theoretical assumptions about combined online customization frameworks, which might later be confirmed or denied at a level of practical research or theoretical dispute. The modification of the traditional Robinson (2008a, 2008b, 2015) conceptual modelling framework used by the author is provided in Figure 2. The main modification here is moving a feedback loop from the Outputs part via Model Objectives to Inputs parts, there so ensuring a continuous evolvement of the framework. Consequently, the urge to implement this modification is closely related to the third aim of the research to provide a clear and closed theoretical standpoint for future researchers in this field. According to Figure 2, the inputs or experimental factors are composed of 3 values, each containing Alternative based, Attribute-based and Question-based framework. 
G., Baranauskas. Digitalization Impact on Transformations of Mass Customization Concept: Conceptual Modelling of Online Customization Frameworks.

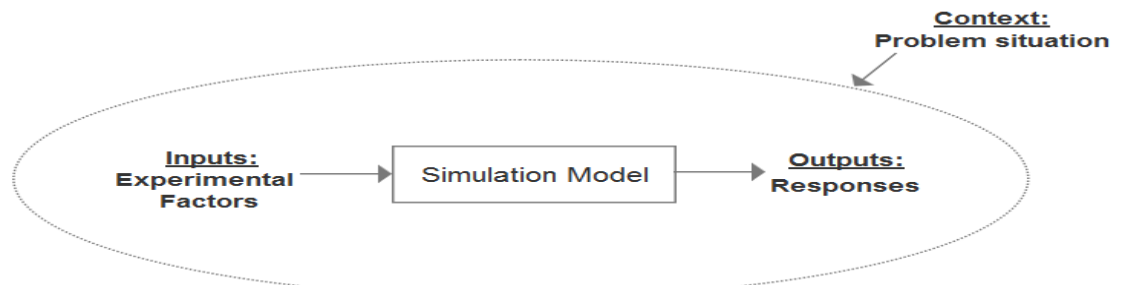

Figure 2. Modification of Robinson (2008a, 2008b, 2015) conceptual modelling framework Source: developed by the author on the basis of Robinson, 2008a, 2008b, 2015.

The stage of the simulation model is conducted following the logic of the c-tuple method. Here, the ctuple method means using 1 of 3 typical online customization frameworks, which has 3 features: low, medium or high value of customization, personalization and standardization level.

The c-tuple method is applied to combine a new set of objects with unique features by choosing one value from each framework and comparing it to values of features in another framework (Haag and Haag, 2019). Outputs or multiplication process responses of the above-defined simulation model stage are at a high abstraction and assumption levels, as well as they, stand for the new Cartesian type of 6 products, which in the following research is called 6 combined online customization frameworks. Moreover, the problem or the context in this conceptual framework could be defined as a practical situation and a continuous improvement need for modern organizations by finding out new formats of online sales and customer service platforms, which definitely help in building a strong competence, innovations and efficiency in a digital area as well as to deal with a pressure of multiple internal and external challenges and business environment, as defined in Table 1. The stage of the Simulation model is conducted by applying a simplified logic of Cartesian product creation by using the c-tuple method in the back-end of the simulation process. The outcome of conceptual modelling is provided in Table 3.

Table 3. 9 theoretical combinations of online customization frameworks

\begin{tabular}{|c|c|c|c|}
\hline Types & Alternative-based (AL-B) & $\begin{array}{c}\text { Attribute-based } \\
(\mathrm{AT}-\mathrm{B})\end{array}$ & $\begin{array}{c}\text { Question-based } \\
(\mathrm{Q}-\mathrm{B})\end{array}$ \\
\hline Alternative-based (AL-B) & $(\mathrm{AL}-\mathrm{B})$ & $(\mathrm{AL}-\mathrm{B})+(\mathrm{AT}-\mathrm{B})$ & $(\mathrm{AL}-\mathrm{B})+(\mathrm{Q}-\mathrm{B})$ \\
\hline Attribute-based (AT-B) & $(\mathrm{AT}-\mathrm{B})+(\mathrm{AL}-\mathrm{B})$ & $(\mathrm{AT}-\mathrm{B})$ & $(\mathrm{AT}-\mathrm{B})+(\mathrm{Q}-\mathrm{B})$ \\
\hline Question-based (Q-B) & $(\mathrm{Q}-\mathrm{B})+(\mathrm{AL}-\mathrm{B})$ & $(\mathrm{Q}-\mathrm{B})+(\mathrm{AT}-\mathrm{B})$ & $(\mathrm{Q}-\mathrm{B})$ \\
\hline
\end{tabular}

Source: developed by the author based on Kamis et al., 2004; Baranauskas, 2020.

As per Table 3 above, 6 combined online customization frameworks with following values of customization, personalization and standardization are identified:

1. In the case of combined frameworks version, where a predominant model is an Alternative based (AL-B), two new possible side options are identified:

1.1. At (AL-B) + (AT-B) the level of customization varies in a full scale from Low to High, at personalization it varies in half of the scale from Low to Middle, while at standardization it varies in a reverse path from High to Middle.

1.2. At $(A L-B)+(Q-B)$ the level of customization and personalization is from Low to High, while at standardization it is from High to Low.

1.3. These two combined options defined above mark a few trends and specifics of e-retailers and an online customer. First, applying elements and values of Attribute-based or Question-based customization frameworks together with the Alternative based customization framework allows organizations to be more agile and flexible in the sense of end-user involvement as well as gives a 
G., Baranauskas. Digitalization Impact on Transformations of Mass Customization Concept: Conceptual Modelling of Online Customization Frameworks.

versatility through the customization process. Moreover, these combinations fit for organizations, which focus on the low or middle level of complexity products/service or have a related diversification strategy with Product/Service Add-Ons.

2. In the case of combined frameworks version, where the predominant model is an Attribute-based $(A L-B)$, two new possible side options are identified:

2.1. At $(A T-B)+(A L-B)$ the level of customization varies in a decrease type of scale from High to Low, at personalization it varies in half of the scale from Middle to Low, while at standardization it varies in an increasing tendency from Middle to High;

2.2. At $(A T-B)+(Q-B)$ the level of customization is High, at personalization level it is in a scale from Middle to High, while at standardization it varies from High to Low.

2.3. Accordingly, the first combined customization framework can be called a reversed version of $(A L-B)+(A T-B)$ combined customization framework. It can be applied in a practical case where organizations select an unrelated diversification strategy by adding a fixed price and content type of Product/Service Add-Ons. It also refers to practical situations where organizations are in a transition period from bricks and mortar type of business model to the online business model. Therefore, in the early stages, this type of organizations uses a multichannel approach with clear customization and personalization limitations and differences for the online version. The second combined customization framework illustrates an opposite trend and can be applied in organizations which are fully digitally and look for online customization and omnichannel improvements.

3. In the case of combined frameworks version, where the predominant model is a Question based $(\mathrm{Q}-\mathrm{B})$, two new possible side options are identified:

3.1. At $(Q-B)+(A L-B)$ the level of customization and personalization varies in a full scale from High to Low, while at standardization it varies in a full scale from Low to High as well;

3.2. At $(Q-B)+(A T-B)$ the level of customization is High, at personalization level, it varies in a scale from High to Middle. In contrast, at standardization, it varies from Low to Middle.

$(Q-B)+(A L-B)$ and $(Q-B)+(A T-B)$ combined online customization frameworks can be used in organizations which have strong foundations and practices of products/service customization and client service personalization. Here, the main aim can be an improvement of an end-user attitudinal experience through a balanced cognitive effort reduction, which has an outcome of offering a pre-defined customized product/service alternative and presenting additional attributes simultaneously.

After conceptual modelling of 6 new online customization frameworks, it appears that pure online customization frameworks are tough to apply in the context of modern e-retailer organizations and rapidly changing attitude of end-users to customized product/service. Furthermore, it should be noted that some market segments and bricks and mortar type of organizations still have a strong and vital legacy of standardization in their operational strategies. At the same time, a transition to a higher customization, personalization and online customer engagement level is necessary and possible by applying combined online customization frameworks. Here, these new frameworks can support an existing end-user centred design approach by combining a participatory and service design approaches to make them participate in both private and public sectors (Saad-Sulonen et al., 2020).

Conclusions. An intensive digital transformation in the society and transitions in organizations within the last decade significantly have increased both practical and academic attention to sustainable and agile development of new, fully digital customized products and personalized services. Moreover, the Digitalization factor has become recognized as a prerequisite to attain Mass Customization successfully as well as a stand-alone research subdomain in Mass Customization research in the past decade. It is illustrated by the traditional version of the Mass Customization concept shifting to a combined electronic (customer and data-driven) Mass Customization and Personalization (e-MCP) version and increasing a practical need for flexible online customization frameworks and solutions. On the other hand, digitalization 
G., Baranauskas. Digitalization Impact on Transformations of Mass Customization Concept: Conceptual Modelling of Online Customization Frameworks.

not only has had a positively widespread effect on all 3 strategic capabilities and process stages of Mass Customization. It also stands for long- and short-term requirements of end-users data security and management, costly technological setup, a new type of organizational resources and strategical change management capabilities. Following an organizational transition to the e-MCP concept and online customization frameworks, it should be noted that they have made a revolutionary impact by shifting a standard, operating sub-model components based on B2C business models to a modern, economic business model Canvas with Osterwalder's 9 points too. Nevertheless, the selection of the online customization framework depends on multiple factors and rapid changes in the internal and external organizational environment.

Therefore, 3 standard online customization frameworks, which were offered by Kamis et al. (2004) are difficult to apply in the context of modern e-retailers' organizations and digital end-user. Here, the extant by 6 new online customization frameworks were simulated via conceptual modelling process and $c$-tuple method: (AL-B) + (AT-B); (AL-B) + (Q-B); (AT-B) + (AL-B); (AT-B) + (Q-B); (Q-B) + (AL-B); (Q-B) + (AT$B)$. These findings not only confirm research hypothesis $\mathrm{H} 1$ and $\mathrm{H} 2$. It also contributes to the field of modern Mass Customization research. These research results support the theoretical discussion within the existing research gap of finding new ways of better-mixed technological-management, and end-user centred design approaches application for a satisfying design and participation needs of online customers. Besides, it encourages further scientific investigation about 6 new online customization frameworks as the alternative method for modelling of end-users' behaviour in online platforms and customization processes.

On the other hand, research results have several limitations to consider, as there is a need to complete a more comprehensive synthesis of qualitative evidence by conducting a narrative synthesis as well as a qualitative comparative content analysis on data from case studies. Secondly, continuous testing and validation of 6 new online customization frameworks are necessary as a feedback loop part is missing in the currently selected conceptual modelling framework. Moreover, a further topic analysis requires evaluating the influence of these frameworks to a digital end-user behaviour, their role, attitude aspects as well as to examine the context and influence of data-driven service and participatory design.

Author Contributions: Conceptualization, G.B.; methodology, G. B.; software, G. B.; validation, G. B; formal analysis, G. B.; investigation, G. B.; resources, G. B.; data curation, G. B.; writing-original draft preparation, G. B.; writing-review and editing, G. B.; visualization, G. B.; supervision, A. G. R.; project administration, G. B.

Funding: This research received no external funding

\section{References}

Abdallah, A. B., \& Matsui, Y. (2009). The Impact of Lean Practices on Mass Customization and Competitive Performance of Mass-Customizing plants. Proceedings of the 20th Annual Production and Operations Management Society (POMS) Conference, 1-30. [Google Scholar] [CrossRef]

Anislc, Z., Freund, R., \& Suzic, N. (2013). Mass customization and personalization in Southeast Europe. 2013 DAAAM International Scientific Book, 389-416. [Google Scholar] [CrossRef]

Baranauskas, G. (2020). Application of Customization and Personalization in Digital Solutions of Non-Life Insurance Market: a Case Study of Lithuanian, Latvian and Estonian E-Sales Platforms. Paper presented at the 31st EBES international conference, April 15-17, 2020 Warsaw, Poland

Brandao, F. J. S. Paio, A., \& Whitelaw, C. (2016). Mapping Mass Customization. Proceedings of the 35th eCAADe Conference, 2, 417-424. Retrieved from https://www.researchgate.net/publication/319944415 Mapping Mass Customization

Broekhuizen, T. L. J., \& Alsem, K. J. (2002). Success Factors for Mass Customization: A Conceptual Model. Journal of MarketFocused Management, 5(4), 309-330. [Google Scholar] [CrossRef]

Burke, L. A., \& Hutchins, H. M. (2007). Training Transfer: An Integrative Literature Review. Human Resource Development Review, 6(3), 263-296. [Google Scholar] [CrossRef]

Carter, C. M. (2016). The Complete Guide to Generation Alpha, The Children of Millennials. Forbes. Retrieved from https://www.forbes.com/sites/christinecarter/2016/12/21/the-complete-guide-to-generation-alpha-the-children-of- 
G., Baranauskas. Digitalization Impact on Transformations of Mass Customization Concept: Conceptual Modelling of Online Customization Frameworks.

millennials/\#6066870c362

Daaboul, J., Bernard, A., \& Laroche, F. (2009). Knowledge Management, Value Chain Modelling and Simulation as Primary Tools for Mass Customization. Paper presented at International Conference on Concurrent Enterprising, Leiben, Netherlands. [Google Scholar] [CrossRef]

Forbes, H., \& Schaefer, D. (2017). Social Product Development: The Democratization of Design, Manufacture and Innovation. Procedia CIRP 60, 404-409. [Google Scholar] [CrossRef]

Francis, T., \& Hoefel, F. (2018). True Gen': Generation Z and its implications for companies. Mckinsey. Retrieved from https://www.mckinsey.com/industries/consumer-packaged-goods/our-insights/true-gen-generation-z-and-its-implications-forcompanies\#

Gandhi, A., Magar, A., \&, Roberts, R. (2013). How technology can drive the next wave of mass customization. McKinsey on Business 32 , $1-9$. Retrieved from

https://www.mckinsey.com/ /media/mckinsey/dotcom/client service/bto/pdf/mobt32 02-09 masscustom r4.ashx

Gilmore, J. H., \& Pine, B. J. (1997). The four faces of mass customization. Harvard business review, 75(1), 91-102. [Google Scholar] [CrossRef]

Grosso, C., \& Forza, C. (2019). Users' Social-interaction Needs While Shopping via Online Sales Configurators. International Journal of Industrial Engineering and Management (IJIEM), 10(2), 139-154. [Google Scholar] [CrossRef]

Haag, A. (2017). Managing variants of a personalized product. Journal of Intelligent Information Systems, 49, 59-86. [Google Scholar] [CrossRef]

Haag, A., \& Haag, L. (2019). Empowering the use of variant tables in Mass Customization. International Journal of Industrial Engineering and Management, 10(2), 155-170. [Google Scholar] [CrossRef]

Hankammer, S., \& Steiner, F. (2015). Leveraging the Sustainability Potential of Mass Customization through Product Service Systems in the Consumer Electronics Industry. Procedia CIRP, 30, 504-509. [Google Schoolar] [CrossRef]

Hong, Q. N., Pluye, P., Bujold, M., \& Wassef, M. (2017). Convergent and sequential synthesis designs: implications for conducting and reporting systematic reviews of qualitative and quantitative evidence. Systematic Reviews, 6(61), 1-14. [Google Scholar] [CrossRef]

Hora, M., Hankammer, S., Canetta, L., Sel., S. K., Gomez, S., \& Gahrens, S. (2016). Designing Business Models for Sustainable Mass Customization: A Framework Proposal. International Journal of Industrial Engineering and Management, 7(4), 143-152. [Google Scholar]

Hu, S. J. (2013). Evolving Paradigms of Manufacturing: From Mass Production to Mass Customization and Personalization. Procedia CIRP 7, 3-8. [Google Scholar] [CrossRef]

Joergensen, K. A., Brunoe, T. D., Taps, S., \& Nielsen, K. (2014). Customization issues: A Four Level Customization Model. Proceedings of the 7th World Conference on Mass Customization, Personalization, and Co-Creation (MCPC 2014), 73-82. [Google Scholar] [CrossRef]

Kamis, A., Koufaris, M., \& Stern, T. (2004). Online Mass Customization and the Customer Experience. AMCIS 2004 Proceedings, 481. [Google Scholar]

Kamis, A., Stern, T., \& Ladik, D.M. (2008) A flow-based model of web site intentions when users customize products in business-to-consumer electronic commerce. Information Systems Frontiers, 12, 157-168. [Google Schoolar] [CrossRef]

Kanama, D. (2018). Manufacturing Transformation toward Mass Customization and Personalization in the Traditional Food Industry. In A. Petrillo, R. Cioffi \& F. De Felice, Digital Transformation in Smart Manufacturing (p. 59-74). London: IntechOpen. [Google Scholar] [CrossRef]

Kaplan, A. M., \& Haenlein, M. (2006). Toward a Parsimonious Definition of Traditional and Electronic Mass Customization. The Journal of Product Innovation Management, 23, 168-182. [Google Scholar] [CrossRef]

Karwatzki, S., Dytynko, O., Trenz, M., \& Veit, D. (2017). Beyond the Personalization-Privacy Paradox: Privacy Valuation, Transparency Features, and Service Personalization. Journal of Management Information Systems, 34(2), 369-400. [Google Scholar] [CrossRef]

Lai, P. (2017). The literature review of technology adoption models and theories for the novelty technology. Journal of Information Systems and Technology Management, 14(1), 21-38. [Google Scholar] [CrossRef]

Lee, C. H. S., Barua, A., \& Whinston, A. B. (2000). The complementarity of mass customization and electronic commerce. Economics of Innovation and New Technology, 9(2), 81-110. [Google Scholar] [CrossRef]

Lee, Z. W. Y., Chan, T. K. H., Loong-Chong, A. Y., \& Thadani, D. R. (2019) Customer engagement through omnichanne retailing: The effects of multichannel integration quality. Industrial Marketing Management, 77, 90-101. [Google Scholar] [CrossRef] Mccarthy, I. P. (2004). Special issue editorial: the what, why and how of mass customization. Production Planning \& Control, 15(4), 347-351. [Google Scholar] [CrossRef]

Medini, K., Le Duigou, J., Da Cunha, C., \& Bernard, A. (2015). Investigating mass customization and sustainability compatibilities. International Journal of Engineering, Science and Technology, 7(1), 11-20. [Google Scholar] [CrossRef]

Morelli, N., \& Nielsen, L. M. (2009). Beyond mass customization: exploring the features of a new paradigm. In F. T. Piller \& M. M. Tseng, Handbook of Research in Mass Customization and Personalization (p. 97-117). World Scientific. [Google Scholar] [CrossRef]

Park, M. \& Yoo, J. (2018). Benefits of mass customized products: moderating role of product involvement and fashion 

Online Customization Frameworks.

innovativeness. Heliyon, 4(2), 1-25. [Google Scholar] [CrossRef]

Piller, F. T., Harzer, T., Ihl, C., \& Salvador, F. (2014). Strategic Capabilities of Mass Customization Based E-Commerce: Construct Development \& Empirical Test, Conference. Proceedings of the 2014 47th Hawaii International Conference on System Sciences, 1-10. [Google Scholar] [CrossRef]

Pourabdollahian, G., Steiner, F., Rasmussen, O. G., \& Hankammer, S. (2014b) A contribution toward a research agenda: identifying impact factors of mass customization on environmental sustainability. International Journal of Industrial Engineering and Management (IJIEM), 5(4), 169-178. [Google Scholar]

Pourabdollahian, G., Taisch, M., \& Piller, F. T. (2014a). Is Sustainable Mass Customization an Oxymoron? An Empirical Study to Analyze the Environmental Impacts of a MC Business Model. Proceedings of the 7th World Conference on Mass Customization, Personalization, and Co-Creation, 301-310. [Google Scholar] [CrossRef]

Reichwald, R., Piller, F. T., \& Moslein, K. (2000). Mass Customization Concepts for the Economy: Four Strategies to Create Competitive Advantage with Customized Goods and Services on the Internet. Paper presented at the International NAISO Congress on Information Science Innovations ISI 2000, Workshop on Information Systems for Mass Customization ISMC 2000, March 17-21, 2001, American University in Dubai, U.A.E [Google Scholar]

Risdiyono, R., \& Koomsap, P. (2013). Design by Customer: Concept and Applications. Journal of Intelligent Manufacturing, 24(2), 295-311. [Google Scholar] [CrossRef]

Risdiyono, R., Widodo, I. D., \& Mahtarami, A. (2016). Mass Customization and Personalization Prospects in Developing Country: Indonesian Context. IOP Conference Series: Materials Science and Engineering, 105, 1-5. [Google Scholar] [CrossRef]

Robinson, S. (2008a). Conceptual modelling for simulation Part II: A framework for conceptual modelling. Journal of the Operational Research Society, 59(3), 291-304. [Google Scholar] [CrossRef]

Robinson, S. (2008b). Conceptual Modelling for Simulation Part I: Definition and Requirements. Journal of the Operational Research Society, 59(3), 278-290. [Google Schoolar] [CrossRef]

Robinson, S. (2015). A tutorial on conceptual modeling for simulation. Proceedings of the 2015 Winter Simulation Conference, 1820-1834. [Google Scholar] [CrossRef]

Rodseth, H., Schjolberg, P., \& Marhau, A. (2017). Deep digital maintenance. Advance Manufacturing, 4, 299-310. [Google Scholar] [CrossRef]

Rungtusanatham, M. J., \& Salvador, F. (2008). From Mass Production to Mass Customization: Hindrance Factors, Structural Inertia, and Transition Hazard. Production and Operations Management, 17(3), 385-396. [Google Scholar] [CrossRef]

Saad-Sulonen, J., De Gotzen, A., Morelli, N., \& Simeone, L (2020) Service design and participatory design: time to join forces? Proceedings of the 16th Participatory Design Conference 2020, Association for Computing Machinery, 2, 76-81. [Google Scholar] [CrossRef]

Salvador, F., Holan, P. D. \& Piller. F. T. (2009). Cracking the Code of Mass Customization. MIT Sloan Management Review, 50(3), 71-79. [Google Scholar]

Schubert, P. (2006). A Project Method for the Personalization of E-Commerce applications in SMEs. Journal of Electronic Commerce in Organizations, 2(3), 21-39. [Google Scholar] [CrossRef]

Snyder, H. (2019). Literature review as a research methodology: An overview and guidelines. Journal of Business Research, 104, 333-339. [Google Scholar] [CrossRef]

Tiihonen, J., \& Felfernig, A. (2017). An introduction to personalization and mass customization. Journal of Intelligent Information Systems, 49, 1-7. [Google Scholar] [CrossRef]

Vekic, A., Borocki, J., Fajsi, A., \& Moraca, S. (2018). Adapting Business Model and Strategies for Next Wave of Mass Customization. Proceedings of 8th International Conference on Mass Customization and Personalization - Community of Europe (MCP-CE 2018), 316-321. [Google Scholar]

Verhoefa, P. C., Kannanb, P. K. \& JeffreyInmanc, J. (2015). From Multi-Channel Retailing to Omni-Channel Retailing:

Introduction to the Special Issue on Multi-Channel Retailing. Journal of Retailing, 91(2), 174-181. [Google Scholar] [CrossRef]

Wang, Q., Wang, Z., \& Zhao, X. (2015). Strategic orientations and mass customization capability: the moderating effect of product life cycle. International Journal of Production Research, 53(17), 5278-5295. [Google Scholar] [CrossRef]

Wang, X., Wang, Y., Tao, F., \& Liu, A. (2020). New Paradigm of Data-Driven Smart Customisation through Digital Twin. Journal of Manufacturing Systems. [Google Scholar] [CrossRef]

Wang, Y., Ma, H. S., Yang, J. H., \& Wang, K. S. (2017). Industry 4.0: a way from mass customization to mass personalization production. Advance Manufacturing, 4, 310-321. [Google Scholar] [CrossRef]

Wang., S. S. (2019). Integrated framework for information security investment and cyber insurance. Pacific-Basin Finance Journal, 57, 1-12. [Google Scholar] [CrossRef]

Weber, M., \& Chatzopoulos, C. G. (2019). Digital customer experience: the risk of ignoring the non-digital experience. International Journal of Industrial Engineering and Management (IJIEM), 10(3), 201-210. [Google Scholar] [CrossRef]

Xu, Y. Chen, G. \& Zheng, J. (2016). An integrated solution-KAGFM for mass customization in customer-oriented product design under cloud manufacturing environment. The International Journal of Advanced Manufacturing Technology, 84(1-4), 85-101. [Google Scholar] [CrossRef]

Xu, Y., Landon, Y., Segonds, S., \& Zhang, Y. (2017). A decision support model in mass customization. Computers \& industrial engineering, 114, 11-21. [Google Scholar] [CrossRef] 
G., Baranauskas. Digitalization Impact on Transformations of Mass Customization Concept: Conceptual Modelling of Online Customization Frameworks.

Yao, J. M. (2017). Supply chain resources integration optimization in B2C online shopping. International Journal of Production Research, 55(17), 5079-5094. [Google Scholar] [CrossRef]

Zhang, C., Chen, D., Tao, F., \& Liu, A. (2019). Data Driven Smart Customization. Procedia CIRP, 564-569. [Google Scholar] [CrossRef]

Zhao, H., McLoughlin, L., Adzhiev, V., \& Pasko, A. (2018). «Why do we buy mass customized products? »- consumer's perspective of success factors for online mass customization. Proceedings of 8 th International Conference on Mass Customization and Personalization Community of Europe: Digital Customer Experience, 1-8. [Google Scholar]

Гєдас Баранаускас, Університет Миколаса Ромеріса, Литва

Вплив діджиталізації на концепцію масової кастомізації: моделювання онлайн кастомізації

У статті систематизовано ареументи та контраргументи у рамках наукової дискусії щодо впливу діджиталізаціі на еволіцію концепції масової кастомізації. Автором визначено, що протягом двох десятиліть XXI століття відбулися суттєві зміни в концепції масової кастомізації Так, інтенсивне застосування комбінованих технологічних та управлінських рішень, розвиток иифрового суспільства та трансформаиія бізнесу змінили орієнтири досліджуваної концепиії на управління нематеріальними продуктами, залучення клієнтів та створення взаємної доданої вартості в онлайн середовищі. Головною метою дослідження є визначення ролі субдомену цифрровізації та його впливу на концепцію масової кастомізації. У статті висвітлено особливості процесу трансформації концепції кастомізації та здійснено моделювання нових комбінацій налаштувань онлайн кастомізації. Актуальність досліджуваної наукової проблеми полягає у необхідності вирішення питань щодо впровадження сучасних та змішаних методів управління компаніями на основі підходу масової кастомізації. Дослідження проведено в наступній логічній послідовності: 1) визначено вплив субдомену цифрровізації на трансформацію теорії традиційної концепиії масової кастомізації; 2) здійснено емпіричний аналіз організаційного переходу до електронних систем масової кастомізації та персоналізації, а також онлайн-налаштувань. Практичну реалізацію всіх етапів дослідження здійснено з використанням інструментарію комплексного бібліографбічного аналізу, наративного синтезу літературних джерел та спрощеної концептуальної моделі Робінсона. Підгрунтям дослідження стали 53 наукові публікації. Отримані результати емпірично підтверджують та теоретично доводять, що впродовж останнього десятиліття у бізнес та науковому середовищах, значно зросла увага до сталого та гнучкого розвитку нових, цифррових індивідуальних товарів та персоніфікованих послуд, а також гнучких онлайнналаштувань та рішень. У статті запропоновано 6 нових систем онлайн-налаштувань на зміну 3 стандартним теоретичним системам, які складно застосовувати в онлайн середовищі. Отримані результати можуть бути корисними для подальших наукових досліджень та перевірки запропонованих систем онлайн-налаштувань з метою оцінювання їх впливу на поведінку кінцевих цифррових користувачів

Ключові слова: кастомізація, діджитал, онлайн середовище, персоналізація, стандартизація.

Manuscript received: 26.02 .2020

(C) The author(s) 2020. This article is published with open access at Sumy State University. 